\title{
An Outline of the Concept of Entrepreneur: Tradition and Modernity
}

\author{
Ionica Oncioiu $^{1 *}$ \\ ${ }^{1}$ Tomis University Constant, Constanta, Romania \\ *Corresponding author: Ionica Oncioiu, Tomis University Constanta, 5A Brizei Street, Bl. \\ FB7A, ap. 1, Constanta, Romania. Tel: 40-744-322911 E-mail: nelly_oncioiu@yahoo.com
}

Received: May 21, 2012 Accepted: June 21, 2012 Online Published: August 25, 2012

doi:10.5296/rae.v4i3.1722ＵRL: http://dx.doi.org/10.5296/rae.v4i3.1722

\begin{abstract}
To be an entrepreneur supposes a special sense of forecast, a certain attitude regarding the activity carried out as well as unique responsibilities. Over time, a problem in entrepreneurship research has been the difficulty of defining the concept of entrepreneurship. Therefore, inquiries into the evolution of this concept have become one of the most popular fields of research in management studies.

This paper presents a historical outline of entrepreneurship from a conceptual perspective, concentrating on whether past and current entrepreneurship theories can adequately embrace forms and patterns of entrepreneurship.
\end{abstract}

Keywords: entrepreneur, evolution, process 


\section{Introduction}

The concept related to entrepreneur has been widely used since the oldest times up to present times, as it is encountered in the specialized literature under different aspects. The notion of entrepreneur originates from the French word "entreprendre", which means to carry on, to get involved in the creation of a thing, to engage into something.

In the older times, the typical entrepreneur could be encountered among the militaries and merchants, since wars were often carried out due to economic reasons. The military leaders, assuming considerable risks, could obtain consistent gains if they had a successful strategy, and the merchants used to risk their fortunes in this context too. Often, the merchant and the fortune hunter were the same person. Marco Polo, for example, was a fortune hunter who wanted to settle trade routes to the Far East. The merchant - fortune hunter assumed the physical and emotional risk of such an action, and the capitalist assumed the economic risk. At the end of the mission, the capitalist received $75 \%$ of the gain, and the merchant received the difference.

Further, due to the fact that in the Middle Ages the trade was considered a degrading activity and because of the restrictions imposed by the Church over the capital offer, the typical entrepreneur was a clerk. He was in charge, for example, of the construction of great architectural works, such as castles, fortresses, public buildings, monasteries or cathedrals. Being engaged in such extensive projects, the entrepreneur did not assume any risk; moreover, he was a project leader that used the resources supplied by the commanding party most of the times. Although their main concern was deontology, the medieval writers asserted nevertheless that a good merchant must be balanced when it comes to risks and well informed in terms of the merchandise quality, price and costs, but also must carefully consider details and be emotionally prepared in case of failure.

The 17th century entrepreneur was the person that concluded a contractual arrangement with the government in order to provide a service or to purchase a certain product, assuming the risk related to such transactions. Although the contractual price was fixed, the entrepreneur could gain or lose following to such transaction, according to his purchase: at a lower or higher price. In England, the land speculators and the farmers were also considered as entrepreneurs.

In the 18th century, the role of the entrepreneur in the economic theory is recognized for the first time. Among the authors that approached the issue of the entrepreneur, one may mention Richard Cantillon, Adam Smith, Jean Baptiste Say, Johann Heinrich von Thünen, J. M. Keynes, Joseph Schumpeter, Peter Drucker, Leon Walras, and others. Richard Cantillon, a French economist, associated the economic risk assumption with the entrepreneur. For Cantillon, the entrepreneur was a person that assumes risks, since he/she buys at a fixed price, he/she sells at a doubtful price, and in consequence, he/she acts in risky conditions. He considered the entrepreneur as the main figure in the economy.

The term "fortune hunter", which is associated to the entrepreneur, was slowly replaced by "undertaker", entrepreneur, about whom Adam Smith wrote first that it became synonym 
with the common businessman. That period was associated to the industrial revolution in England, process by which the entrepreneur had a visible role in assuming the risk and transforming the resources. At the same time, the entrepreneur proved to have a special capitalist spirit. The many inventions during the industrial revolution had not been possible without the support of those persons that held capital, but they did not possess the skills of an entrepreneur.

In the 19th century, the entrepreneur was better identified from an economic point of view. As a rule, he/she was not different from the manager. For the first time in the economic literature, the entrepreneurial activity becomes synonymous with management, in the contemporary sense of the word.

The lack of importance granted to the entrepreneurial management was seriously discussed on two notorious occasions in the 20th century. The first occasion was the publishing of Frank Knight's work entitled "Risk, uncertainness and profit" (1921), a famous work at its time, but less read afterwards. 10 years before the advent of Knight's book, the young Joseph Schumpeter manifested a very different opinion over the economic issue in the "Theory of economic development" (1912). Did one reach an accurate understanding of the entrepreneur's characteristics, functions and importance by the 21 st century?

\section{Main perspectives on the entrepreneur}

Adam Smith gave a theoretic expression to many phenomena, processes, categories, laws as well as to the market economy related mechanism itself, under the forms specific to the 18th century. However, his ideas and his work represented the inspirational source critical, neutral or creative - for many types of schools and economic thinking trends.

The harmonization of the particular with the general, of the national with the universal offered his theoretic creation a value that has not been diminished in time, and the "Wealth of Nations" is recognized as the masterpiece in which the economy as a science gained precise outlines and became a self - contained field. Smith's economic conception as presented in the "Wealth of Nations" results from his previous writings, among which one distinguishes the importance of "The Theory of Moral Feelings" (1759). The central issue of his work is determining the means by which men formulate a moral judgment (assertion of certain ideas about vices and virtue, about the good and the bad, about just and unjust). In terms of the generality and universality of Smith's theory, he is an international classic, not only a classic of a country and social category, and his masterpiece remains one of the most important reference moments in the cumulative process of economic science development.

An admirer of Adam Smith's ideas, the French economist and advocate of liberalism Jean Baptiste Say, was born in Lyon in a family of Protestant merchants. He received an education that would mark both his writings as well as his practical behavior. At the age of 19 he goes to England, where he deems fit to insert a specific order in the ideas of Smith in his "Treatise of political economy" (1803) and in his last work "Complete course of practical political economy" (1828-1829). Interested in politics, he returns to France, where he embraces the new ideas of the French Revolution, which made the apology of liberty and 
equality by abolishment of privileges. He becomes a tribune, but due to his disagreement with the ideas of Napoleon Bonaparte, which were too interventionist, he drifts away from the political activity.

J. S. Mill (1806-1873), known as the last great classic liberalist and the first modern liberalist, son of James Mill, a professor of economy, has been considered by some authors as a "wonder child", since he was preoccupied at the age of 3 by arithmetic and Hellenic studies, and at the age of 13 by economic studies. The writings of Ricardo, Hume and Bentham were part of his youth universe. At the age of 14, he leaves to France, upon the invitation of his brother Bentham, and in Paris, he meets Jean Baptiste Say, with whom he will have a tight and long-lasting friendship, as well as Saint-Simon, who had managed to be famous in the field of economic theory.

Returned to England in 1821, where meanwhile his father had completed his work "Elements of Political Economics", young Mill would draft a detailed resume of the manuscript that he publishes under the name of his father. In parallel with the scientific studies, Mill had been working for 30 years as an employee of the East India Company. His work entitled "Principles of Political Economics" (1848) represents a quintessence of what had been more valuable in the economic science up to him, to which he added his own ideas on the matter.

Leon Walras (1834-1910), professor of political economy at the University of Laussane, is considered as "the first founder of modern economic science" or "the greatest economist of all times", and his scheme over the general balance is appreciated as "The Great Charter of Economic Theory". The period 1871-1892 was the most productive period of Leon Walras activity. Then he created the elements that materialized in contributions to the occurrence of the marginal revolution, mainly aimed on the mathematic explanation and formalization of general balance. He stated "I progressively elaborated the entire theory of economic balance, first of all in four memoirs: The principles of a mathematic theory of exchange (1873), Exchange equations (1875), Capitalization equations (1875), and then "Elements of Pure Economics" (1874-1877)" (Hebert, 1989).

John Maynard Keynes, born in Cambridge in 1833, is the member of the new group of economists, who influenced the economic political decisions of the Western countries starting with the end of World War I. At 14, he studies at Eton and later on enrolled at Cambridge University to study mathematics. After graduation, he becomes a lecturer in economics at the same university. He knew better than the theory the new realities, the acute problems that the economies of the world countries coped with after World War I.

The market economy - perceived by the classical economists under its positive aspects, and by the socialist economists under its negative aspects - demanded to be reexamined from a critical point of view following which remedies were about to be brought to it. Starting with his few ideas sensed in "The Economic Consequences of Peace" (1919), which were developed and completed by the author with others in "Treatise over Money (1930), J. M. Keynes reaches a theoretical system that he states in his work "General Theory in Using the Workforce, Interest and Money" (1936). In this work, the author is detached from classicism 
and neoclassicism and a new paradigm is born in the economic science.

Joseph Schumpeter, although of German origins, was born in 1883 at Triesch, a Czech city of approximately 5000 inhabitants, which subsequently became part of the Austro Hungarian Empire. Under the influence of his stepfather, a retired lieutenant colonel in infantry, he studied at Theresianum school of Vienna, where the children of Austro Hungarian aristocracy used to study according to tradition. In 1901, he was enrolled at Vienna University, where he studied the social history and law history. Later on, his tendency was related to economic theory and he graduated as Doctor in 1906. His first relevant work, "The Theory of Economic Development", was published in 1911.

Although Schumpeter was not a Marxist, he studied Marx and liberals and in 1918, he became a member of the German Socialization Commission. This led to his appointment as Finance Minister in 1919. Nevertheless, in less than a year after his appointment, he was dismissed from his position due to his failure to unite the broken political forces. He returned to the academic world in 1932 and accepted the position of professor at Harvard University.

Along his career, Schumpeter was recognized as a unique and bright economist, who held many conferences in Europe, America and Japan.

Schumpeter was trained as a historical economist, but he was an early advocate of mathematics application in the economic theory. Nevertheless, he despised the mathematic patterns based on Adam Smith's theories, as he was included along with Marx, Weber and Tawney in the "stadial theory" or among the historical economists. These economists perceive the changes occurred in economy as a proof of the structural changes occurred within the society.

An admirer of Weber, Schumpeter was a permanent supporter of Weber's concept regarding the "social economy" - a reunion of sociology, economy and history in one discipline. He considered Weber as being more of a sociologist than an economist and himself as being more of an economist than a sociologist. He perceived Marx in the same manner, admiring his observations, but not his conclusions in the economic field. Nevertheless, he differs from other economists by the way in which he perceives the business cycle.

Peter Drucker, in his 60-year career, published 29 books, an average of one book in two years. His work is divided in three categories: social and political analysis books such as "The Future of Industrial Man" (1942) or "The Age of Discontinuity" (1969), management books such as "The Practice of Management" (1974) or "Management: Tasks, Responsibilities, Practices" (1974), and practical advice books for managers such as "Managing for Results" (1964) or "The Effective Executive" (1966). In addition, he gathered his essays on a regular basis in books such as "The Frontiers of Management" (1986) and “The Ecological Vision" (1993).

Nevertheless, his books are just half of his masterpiece. Along the years, Drucker wrote hundreds of articles. From 1975 until 1995, he wrote a monthly column, very often quoted, on the Wall Street Journal editorial page. At the same time, which is regarded by him as "the 
period of my greatest productivity", he wrote 22 essays of 3500 - 6000 words each: eight for Harvard Business Review, three for The Public Interest, three for The Atlantic Monthly, two for Foreign Affairs, two for The Economist and one for New Perspectives, Inc., Forbes and Esquire. He gathered his best essays written in more than 50 years in his volume entitled "The Ecological Vision". He also wrote two novels and managed to publish three books about management and four books about "society, economy and politics", including the latest one, Drucker on Asia, which was written for the Japanese market and that appeared in English Language in 1997, and now is being translated in Korean, Portuguese, German, French, Spanish and Thai.

\section{The entrepreneur in the conception of classic liberalism}

Adam Smith, as a representative of classic liberalism, did not distinguish between capitalist as holder of financial "stock" and entrepreneur (manager) as a final elaborator of decisions. Nevertheless, in the "Wealth of Nations", Adam Smith clearly separated the functions pertaining to the capitalist and those of a manager and he emphasized the fact that the "profits" pertaining to the capitalist exclude management "salaries" as payment for "inspection and directorate work". The capitalists are the privileged of the economic system. They "get away" from the competition since they hold the "manufacturing" secrets and they may unite themselves in powerful coalitions, holding information to which the other social categories cannot have access. Thus, they adopt a position by means of which they can influence the political authority, giving the impression that the general interest coincides with their personal interest.

Smith's conviction, which is based upon factual observations, was that "to the extent to which the capital accumulation is anticipated to be necessary to continue the great perfection of the work productive forces, the accumulation normally leads to such perfection. The person (capitalist) who uses his capital by making use of other's work is obviously willing to use it in such a way that he manufactures as much products as possible. This is the reason why the capitalist strives both to share the work quantity among his workers in an equitable manner as well as to supply the best machines that he may invent or afford to buy" (Smith, 1976).

The first clear emphasis of the entrepreneur's role is found at Thünen, who defines the entrepreneurial gain as the income resulted apart from gross profits resulted from business operations after the payment of interests on capital invested, of management salaries and of the insurance premium against the loss calculated risk. Regarding the entrepreneur, Thünen tells us that the insurance premiums related to risks must cover them because the risks are unpredictable. From here, given the fact that it is impossible to state the probability of gains or losses, the entrepreneur is necessary in terms of "innovator and exploiter in his field". Thus, we must observe the entrepreneur's artistry in settling the risk related covering residual income, which is an unpredictable income.

The French economist J. B. Say stated in 1800 that the entrepreneur takes out the economic resources from a field of low productivity and inserts them in a field of high productivity and higher yield. However, his definition does not identify the "entrepreneur". 
Since Say invented such theory almost 200 years ago, there was a total confusion regarding the definition of "entrepreneur" and "entrepreneurial system".

Emphasizing the qualities of an entrepreneur, Say asserts that he/she needs "a combination of moral qualities, judgment, perseverance and knowledge of the world and business". Say was an admirer of Adam Smith: he translated Smith's work "Wealth of Nations" in French language in 1776 and ceaselessly spread during his entire life, Smith's ideas and political trends. The industrial revolution marked Say's conception over economy, in some aspects detaching him from Smith in a positive way. However, his personal contribution to the economic thinking, the concept of entrepreneur and entrepreneurial system is independent from the classic economy and indeed it is incompatible with it.

According to Say's opinion, the entrepreneur is a supervisor and an administrator. $\mathrm{He} / \mathrm{she}$ needs to accurately assess the importance of a new product, the demand level as well as the level of production means. At a specific moment, he/she must employ a great number of employees. In other instances, he/she must order or purchase raw materials, to find consumers and to pay a permanent attention to order and economy. In a word, he must possess the art of supervision and administration.

The theory understands the change as being normal or even healthy and the major task in the society - especially in economy - of doing something different and not doing the things that have already been done in a better way. This is the essential part of Say's understanding when he invented the term entrepreneur. It was like a manifest and a statement of disagreement: the entrepreneur concerns and disorganizes. His task, as it was later on formulated by Schumpeter, is the "creating destruction", as the entrepreneurship is an ongoing event of the economic reform.

In Say's opinion, the entrepreneurs see the change as a model and as something healthy. Usually, the change is not only caused by them. However, the change also defines the entrepreneur and the entrepreneurial system: the entrepreneur always seeks the change, answers to it and exploits it as an opportunity. In a preference scale of the activities that must be encouraged in the national economy, he put the industry in the forefront; he detached the entrepreneur from the capital owner, emphasizing his special role in the wealth production and distribution.

According to Say, the entrepreneurs' capacity - as main agents of the economic progress since the Napoleon times: trained, active, innovative inventors, famers, industrialists and bold and entrepreneur merchants - was the one that exerted the greatest influence over the wealth production, distribution and achievement.

J. S. Mill, in his principles elaborated in 1848, popularized the entrepreneur term among the English economists, but he retained the tradition of considering the entrepreneur as a simple capitalist on multiple facets, as Smith and Ricardo did. Soon after, the margin revolution drifted the attention from internal organization of business enterprise, thus eliminating the role of capitalism and entrepreneur.

At the beginning of 20th century, the entrepreneur became synonym or at least 
associated to free enterprise and capitalism. He/she is recognized as an agent of change. The entrepreneur is a creative person, with innovative ideas in business, who contributes to a company's growth and profitability

\section{The entrepreneur in modern times}

The skillful entrepreneurs best combine the services that generate utilities (that confers value to merchandises) of human, capital and nature factors. In order to procure them, they pay salaries, interests and/or rentals; they use and combine them so that they offer the market the goods and services demanded.

In Germany, there is a distinction between entrepreneur and manager: "The entrepreneur is subject to specific concerns and agitation related to the business world; he does not sleep for nights, he is only preoccupied by the thought of avoiding failure. On the other hand, the manager, if he did a great job during the day and if he is tired, he may have a deep sleep, without any concerns, with the consciousness of his fulfilled tasks" (Low \& MacMillian, 1988). The entrepreneur is considered both an innovator and a person who assumes risks, as his income is divided in two: an income pertaining to the "entrepreneurial risk" and another one that is due to his "cleverness".

In U.S., the entrepreneur is different from the capitalist and he is deemed as "the main production agent". The successful entrepreneur has the power to predict, he has organizational and administrative skills, an exceptional energy and other qualities of a leader (Reynolds, 2000).

Of all-important modern economists, Joseph Schumpeter was the only one that tackled the problem of the entrepreneur and his impact on the economy. Schumpeter may be considered as the prophet of discontinuity era, since he discusses about the passage from a "managerial" economy to an "entrepreneurial" one, that he calls "essential transformation" of the economy. He presented for the first time his concept of "creative destruction" in the "Theory of Economic Dynamics"(Venkataraman, 1997).

For Schumpeter, the economic stages did not represent an inevitable progress of the society. In other words, the capitalism was not inevitably followed by socialism. The capitalism could be rekindled and the entrepreneurs have such a mission. This makes Schumpeter different from other economists, according to Peter Drucker (Zahra S.\& Dess G.G., 2001), since for the traditional economists, "the entrepreneurship" is a "meta-economical" event that deeply influences and shapes the economy without being integral part of it. Therefore, the entrepreneur is the source of all dynamic changes in the economy, and the capitalist system for Schumpeter can only be understood through the prism of development conditions related to entrepreneurial activity.

In "Capitalism, Socialism and Democracy" (1942), Schumpeter asserts that "such process of creative destruction is the main factor of capitalism". He is based on his concept of "entrepreneurial profit". The entrepreneurs reach to such surplus by means of new processes or improvements that prevail over those of their competitors. The new business is then growing up to the stage of oligopoly or monopoly, thus creating an offer surplus. Although the company 
that holds the monopoly tries to control the market, actually it loses the monopoly because it creates a new profit opportunity for the innovative entrepreneur who will find a new process, an improvement or he will simply replace the product.

As in all previous theories about the entrepreneurial activity, also for Schumpeter the entrepreneur has a functional role, which is not necessarily embodied by one physical person or by a well - defined group of people. The entrepreneur may be capitalist or even manager, but if all such different positions are combined to one or more people, then he depends on the nature of capital markets and on the organization forms of the branch.

Schumpeter went further than his predecessors, reckoning that the same person may be an entrepreneur when he/she is an innovative business person, but he/she loses such character immediately after having built or planned his business and having carried them out in routine. Thus, the current entrepreneurs from the capitalist economy change constantly because the management function of the undertaking is normally mixed with other types of activities.

Schumpeter considered that the power of small businesses to create new workplaces comes from the innovative power. Great companies invest huge amounts of money in technology. They are preoccupied to keep such investments no matter the consequences. The entrepreneurs do not have such restrictions. They invest in new technologies and processes. In the main developed countries, such power that the entrepreneurs have is certainly supported by the dramatic technological changes in the technological field. This agrees with Schumpeter's opinion regarding the business cycles in which he sees dramatic technological changes in each 50 to 76 years. The technology of electronic information is a powerful force nowadays, as the steam engine used to be back in time. Its power may be observed in the dramatic growth of Microsoft Company. When David Birch published his study in 1979, Microsoft did not even exist as a concept. Nowadays, its owner is one of the wealthiest men in the world.

Nevertheless, innovation is not limited to new technologies. It is also present in the new modalities of product trading and in the new methods of company management. Although Bill Gates, Microsoft founder, is nowadays one of the wealthiest men in the world, Sam Walton was his predecessor. Walton built a retail empire (Wal-Mart) based on a sophisticated distribution system that allowed him to sell products in rural cities at low prices, products that up to that point in time were only available in big cities. Thus, he left behind more than half a dozen of heirs ranked among the first 500 richest Americans. The objective of successful entrepreneurs does not only consist of making the fortune; they also wish to improve life quality (Sam Walton) or change the way of action on the product and service market (Bill Gates, Steve Jobs, and others).

For Israel Kirzner and Richard Cantillon, the essence of the entrepreneurial activity consists of the personal vigilance to find potential sources of gain. There is a subtle modification of the emphasis in Kirnzer's discussion over the entrepreneurial activity compared to Schumpeter's. Schumpeter portrayed the innovative entrepreneur as an unbalance factor, which disturbs the future balance, while Kirzner describes him/her as identifying the unbalance situation and acting to restore the balance. 
Schumpeter asserted in 1911 that the entrepreneur is the one that innovates, that brings "new combinations" in production. The achievement of new combinations from the existent things is called "enterprise" and the individuals whose task is to fulfill them are called "entrepreneurs". Further, he considers that "The making of an investment is a completely different task from its invention; it is an additional task that demands totally different skills" (Stevenson et. Jarillo, 1990). Although the entrepreneurs may certainly be investors as well, as they may also be capitalists, they are not inventors by the nature of their position, but by coincidence and conversely. In fact, the innovations that must be created by the entrepreneurs by the nature of their position do not necessarily have to be investments.

According to Schumpeter, the entrepreneur must be able to carry out the following combinations: introduction of new production methods, conquest of a new market segment, using a new source of raw materials, and fulfillment of a new organization of the enterprise.

The entrepreneur was also analyzed from psychological point of view. Thus, he is considered to be a person of a great need for personal achievement. In addition, the security, the prestige, the power and services brought to the company are important reasons to maximize profit.

The new Austrian theory about the entrepreneurial activity reduces the entrepreneur's activity to a sort of arbitration, clearing away most of crucial problems that were tackled in connection to it according to tradition (Ebeling, 2003). The popular stereotypy of the entrepreneur as a great boastful business person, narrowed too much the opinion about him/her, but on the other side, the Austrian conception about the entrepreneur as the one that buys cheap and sells expensive may be wrong if generalized.

Frank Knight started to work based on the difference made by Thünen between risk and uncertainness. The risks must be included among the elements of production costs, they must not represent a cause for profit or losses, but they must be deducted on their account. Nevertheless, there are uncertainties that can never be reduced to objective measures, because they involve unforeseeable situations. "The only risk that leads to profit", observes Knight, "is the unique responsibility that results from the exertion of final responsibility, which by its nature cannot be ensured, nor capitalized, nor paid" (Davidson, 2003). The beauty of Knight's argument consists of showing that the presence of a real "uncertainty" over the future allows the entrepreneur to gain positive profits, despite the perfect competition, despite the long-term balance and product exhaustion.

The production replaces the consumption forecast and this is why the demand for production factors is determined by the expected growth of production consumption, as the entrepreneur is forced to speculate the price of his final product. Nevertheless, it is impossible to determine the price for his final product without knowing the payments that must be made for the production factors. The entrepreneur solves such a dilemma by guessing the price at which the production should be sold. Although the factors are engaged on a contractual basis and he must pay the anticipated value of their marginal product, the entrepreneur could determine by the non-contractual residual income a wave of gains, if present income proves to exceed the assessed gains. 
The entrepreneurs are not capitalists, although it is obvious that they need capital, as they need all the economic activities and most of non - economic ones. They are not investors either. They assume the risks, but so does also any employee in any type of activity.

The entrepreneur is not a boss as well, but he may be. He is often an employee or someone that works by himself and on his own. Thus, the entrepreneurial system is a distinctive feature either we are thinking about the individual or about an institution.

To be an entrepreneur is not a personal feature, as Peter Drucker observed, arguing that he had seen in thirty years people having the most diverse personalities and tempers with an appropriate behavior in the entrepreneurial desiderata. Still, it is less probable that the people who need certainties may be good entrepreneurs and the same thing happens with those people who want to manage in a multitude of other activities, such as politics, military service or being captain on a transatlantic ship. All such activities require decision taking for a specific purpose, and the essence of any decision is the uncertainness because anybody may cope with such a situation and anybody can learn how to be a good entrepreneur and to behave accordingly.

Thus, the entrepreneurial system is more connected to the behavior than to the personality, and the grounds rather consist of concept and theory than institution. Any practice is based on theory even if the practitioners themselves are not aware about it. The entrepreneurial system is based on the theory regarding economy and society. Generally, there is a tendency to believe that the entrepreneurial system is extremely risky.

Indeed, in the extremely prominent areas of innovation, as advanced technology - for example, microcomputers or biogenetics - the failure rates are high and the chances to succeed or even to survive in this field seem quite low. But why does it have to be that way? By definition, the entrepreneurs transfer the possibilities from the low productivity areas to the higher productivity and higher yield areas. Obviously, there is a risk in failing to do that. However, if they have moderate success, the profits will be more than enough to compensate any risk that could exist. Thus, the entrepreneurial system should be considered more or less risky than the optimization. Indeed, nothing can be as risky as optimizing the possibilities in areas where the correct and profitable trend is innovation, i.e. where there are already innovation related possibilities.

Theoretically, the entrepreneurial system should be the least risky compared to the majority of risky methods. Obviously, many people think that the entrepreneurial system with a low risk is a stroke of luck, an accident or just a chance. The success average in initiating new businesses is so high that one may combat the popular belief of a high risk entrepreneurial system for many individual entrepreneurs. The entrepreneurial system is risky because few of the so - called entrepreneurs know what they are doing. They lack the methodology and transgress elementary well - known laws. Such a case is especially encountered for those entrepreneurs that use advanced technologies.

The entrepreneurial system and innovation with advanced technologies are intrinsically more risky and more difficult than the innovation based on economy and market structure, on demography or even something as apparently nebulous and intangible as perceptions and 
moods. However, even the entrepreneurial system with advanced technologies should not be so risky, as Bell Lab and IBM demonstrate. They must be well administered and based on innovations of a well - determined purpose.

Any institution, observes Drucker in "Post Capitalist Society", "degenerates in mediocrity and lack of performance if it is not responsible in front of anyone for the results attained. The same thing happened with the great American corporations between 1950 and 1980" (Drucker, 1987). This was the context in which during the 80s, Drucker's attention turned to the entrepreneurial capitalism and to non - profit organizations. Drucker considers that the advent of a "real economy of the entrepreneurs in the United States within the last 10 or 15 years is the most significant event in the recent economic and social history" (Gartner, 1988). Following the publishing of his book 'Innovation and Entrepreneurship', a reporter of Inc. magazine asked Drucker if he agreed with the "conventional wisdom", according to which there are managers and entrepreneurs, but these represent two distinct categories. Drucker' answer was both yes and no: "There is managerial work and entrepreneurial work, but you cannot be a successful entrepreneur if you do not use your managerial skills and if you try to be a manager without being entrepreneur, you are in the risk of becoming a bureaucrat." (Gartner, 1988).

The entrepreneur is the capitalism's hero and Drucker wanted that part of his prestige passes over the manager who needed him too much that particular time. Strangely, Drucker himself, the one who coined the concept of manager did not feel comfortable in using the word manager: "I see that I use the term executive more often because it involves the responsibility of a certain sphere, and not necessarily authority over people"(Drucker, 1987). Further, Drucker was insensitive to the entrepreneur's charm: "The image of innovators is the one of a hybrid between Superman and The Knight of the Round Table. Most of them are not romantic characters in their normal life and they spend hours to draft a project "(Drucker, 1987). There was nothing miraculous in terms of entrepreneurship - a subject matter that could be taught just as mathematics. It is not a romantic aspect, but the biographic circumstances that made the enterprising spirit understandable for Drucker, since it was inoculated by his father's friend of and former colleague at the Faculty of Economics at Vienna University, Joseph Schumpeter.

The essence of the enterprising spirit consists of "doing something else than improving what had already been done". The entrepreneur innovates: "The innovation' is the entrepreneur's specific tool. It endows the sources with a new capacity of inserting prosperity. Although we often talk about it as being a technological change, the innovation is rather an economic or social term than a technical term "(Drucker, 1987).

His work "Innovation and Entrepreneurship" is not intended to be a historical analysis, but nevertheless, it is intriguing that Drucker ignores the role of government in the entrepreneurial revolution of the industries with the high technology recently developed. As Manuel Castells asserts in the first volume of his analysis regarding the information era, "The Rise of the Network Society", the real entrepreneur remained the taxpayer (Drucker, 1987).

In agreement with the vision of contemporary neoclassic scientists, Schumpeter considers that "economy" is preoccupied by the nature of alternative options (allotment of rare resources for competitive purposes), that it represents a mental process and not the study of practical 
processes (Alvarez et all. 2001). It is not limited to a separate sector of human activity, but it refers to all choice related problems that regard both the isolated individual and the organized groups.

The author reminds us that the entrepreneur has a special role to this regard and he shares the idea that the analysis of individual behavior supposes a reasonable behavior. By this, he understands that the individual has preferences, that he/she knows how to express and in consequence, he/she will choose the solutions that improve his condition. This choice will always be made following cost comparison (costs that may pertain to the sacrificed chance) with the advantages of different possible options.

\section{Conclusion}

Adam Smith considered that the capitalists are the privileged of the economic system. They "get away" from competition, since they hold the "manufacturing secrets" and they may unite themselves in powerful coalitions, holding information to which the other social categories cannot have access. This is not possible if one promotes an efficient governing system that excludes or at least limits the entrepreneurs' opportunist behavior, determining them to act with the purpose of meeting the requirements of all people interested in the company's long - term profitable operation and not just in pursuit of their personal objectives or interest coalitions.

Schumpeter formulated the idea that the entrepreneurs are born, and they cannot be trained, while Peter Drucker asserted that being an entrepreneur is not a personal feature, but more behavior, and the management activity may only be successfully practiced if the manager possesses specialized knowledge.

To my opinion, the entrepreneurs must have innate capacities, but such an aspect is not enough if they are not further trained and improved by education. The good entrepreneurs start their activity with their talents that they shape further according to the successful and unsuccessful experiences. In order to be a good entrepreneur one must have what it is commonly called "managerial capacity" to which Say referred to when he used the term "entrepreneurs' capacity" as the one that exerts the greatest influence in the management process and wealth distribution.

A good entrepreneur must be able to train at his turn other entrepreneurs for all hierarchic levels of the company. In consequence, the final test for an entrepreneur is his/her skill to train other entrepreneurs as well. Thus, the behaviorist point of view exceeds the entrepreneur's traditional model, based on innate qualities, since the practice demonstrates that the fulfillment of the objectives is closely conditioned by the training in time of management skills. In the case of many entrepreneurs it is not necessarily the lack of skills, but their incapacity of transmitting a vision, understanding and trust among those that follow him.

As mentioned earlier in this paper, some regard the entrepreneur as being the source of creative destruction and the one who performs new combinations in production. From this perspective, the entrepreneur triggers the change, but one also must take into account that the change is an extremely unsteady process, since along the years, the requirements of a society 
modify. The entrepreneur is always looking for a change, reacts to it and exploits it as an opportunity, as Say noted (Bygrave, 1991). Such qualities stand for the connection that maintains the organization's cohesion, which helps it to formulate and implement coherent strategies, to increase the flexibility and successfully adjust to the change.

Schumpeter is the one that considers that the entrepreneurs are innovators as well, because they perform new combinations of the things already existent. To my opinion, the entrepreneurs are those people that are not necessarily inventors or innovators, but those persons that initiate a business, assuming the risks that normally others cannot afford, with the purpose of recording profit.

Some authors asserted that the entrepreneurs are adventurers, taking in account that they assume risks that others would not assume. To this regard, I consider that the risk is an important element of the entrepreneurial process. Nevertheless, I think that the existent perception regarding the risk assumed by the entrepreneur is wrong because most of the entrepreneurs prepare and plan their actions. Thus, the entrepreneur does not deliberately seek risks and nor he/she assumes them and has no hesitation when it comes to unavoidable risks.

According to the economist Peter Drucker, it is less probable that the people who need certainties be good entrepreneurs. All such undertaking activities require decision taking for a specific purpose, and the essence of any decision is the uncertainty. Anybody may cope with such a situation, can learn how to be a good entrepreneur and to behave accordingly. Uncertainty, doubt, lack of conviction may lead to managerial failures that block the path towards excellence. The lack of conviction supposes the lack of a motivation powerfully anchored in the faith of a prompt, precise and qualitative achievement of the activities, objectives, in the application of new peak methodologies used for products.

The entrepreneur can only manifest the necessary determination to ensure the success by having faith that he/she will be successful in what he/she does, and thus he/she will always advance in the direction of his convictions. Entrepreneurs will most probably fulfill those things that they think themselves capable of fulfilling. This is because there is an extraordinary power in the conviction that one can reach anything one wants to. The one who has a great self - trust is freed from the uncertainness of his/her situation, even if it is precarious and thus, he/she eliminates any uncertainty about the future. In other words, the one that is protected by his/her faith is free from all fears and concerns that may defeat those who have less faith in the things they can achieve. He/she is free to make use of his/her qualities to their maximum value. Nobody is able to make full use of qualities when he/she is over whelmed by worries, anxiety, fear or uncertainty. The entrepreneur represents a topic of great relevance not only for management or entrepreneurship studies or for broader economic studies. In order to better grasp this complex economic actor, an increased input from psychological - behavioral and sociological studies remains of crucial importance. 


\section{References}

Aldrich, H.E., \& Baker, T.B. (1997). Blinded by the cites? Has there been progress in entrepreneurship research? In Sexton, D.L. \& Smilor, R.W. (eds.), Entrepreneurship 2000. Chicago: Upstart Pub Co, 377-400, ISBN: 9781574100648.

Alvarez, S.A., \& Busenitz, L.W. (December 2001). The entrepreneurship of resource-based $\begin{array}{llll}\text { theory. } \quad \text { Journal } & \text { 755-775. }\end{array}$ http://dx.doi.org/10.1177/014920630102700609

Baumol, W.J. (1993). Formal entrepreneurship theory in economics: Existence and bounds. $\begin{array}{llll}\text { Journal of Business } & \text { Venturing, }\end{array}$ http://dx.doi.org/10.1016/0883-9026(93)90027-3

Brockhaus, R.H. (Sep. 1980). Risk taking propensity of entrepreneurs. Academy of Management Journal, 23(3), 509-520. Retrieved from http://www.jstor.org/stable/255515

Bygrave, W.D., \& Hofer, E.W. (Winter 1991). Theorizing about entrepreneurship, Entrepreneurship: Theory and practice, 16(2), 13-22. Retrieved from http://librarylinks.shef.ac.uk:3210/sfxlcl3?u...:sch\%5Fsvc\&

Carland, J.W., Hoy, F., Boulton, W.R., \& Carland, J.E. (April 1984). Differentiating Entrepreneurs from Small Business Owners: A Conceptualization. Academy of Management Review, 9(2), 354-359. Retrieved from http://www.jstor.org/stable/258448

Cunningham, J.B., \& Lischeron, J. (1991). Defining entrepreneurship. Journal of Small Business Management, 29(1), 45-61. http://dx.doi.org/10.1504/IJESB.2007.014395

Davidsson, P. (2003). The Domain of Entrepreneurship Research: Some Suggestions. In Katz, J. \& Shepherd, D. (eds.), Advances in Entrepreneurship, Firm Emergence and Growth, 6(3), 315-372. Greenwich, Plsevier/JAI http://dx.doi.org/10.1016/S1074-7540(03)06010-0

Drucker, P. (1987). Innovation and entrepreneurship. Academy of Management Review, New York: Harper \& Row, 172-175.

Ebeling R. M. (2003). Austrian Economics And The Political Economy of Freedom. Edward Elgar Publishing, ISBN-10: 1840649402.

Gartner, W. B. (1988). Who is an entrepreneur? Is the wrong question. American Journal of Small Business, 12(4),

11-32. http://search.ebscohost.com/direct.asp?db=bth...\&scope=site

Gartner, W.B. (1990). What are we talking about when we talk about entrepreneurship. $\begin{array}{llll}\text { Journal of } \quad \text { Business } & \text { Venturing, }\end{array}$ http://dx.doi.org/10.1016/0883-9026(90)90023-M

Gartner, W.B. (2001). Is there an elephant in entrepreneurship? Blind assumptions in theory development. Entrepreneurship Theory and Practice, 25(4), 27-39. 
http://dx.doi.org/10.1007/3-540-48543-0_11

Hebert, R.F., \& Link, A.N. (1989). In search of the meaning of entrepreneurship. Small Business Economics, 1(1), 39-49. http://dx.doi.org/10.1007/BF00389915

Hoselitz, B.F. (1951). The early history of entrepreneurial theory. Exploration in Entrepreneurial History, 3(4), 193-220.

Katz, J.A. (2003). The chronology and intellectual trajectory of American entrepreneurship education: 1876-1999. Journal of Business Venturing, 18(2), 283-300. http://dx.doi.org/10.1016/S0883-9026(02)00098-8

Low, M.B., \& MacMillan, I. C. (1988). Entrepreneurship: Past research and future challenges, Journal of Management, $14(2), \quad 139-161$. http://dx.doi.org/10.1177/014920638801400202

Morris, M.H. (1999). Entrepreneurial intensity: Sustainable advantages for individuals, organizations and societies. Academy of Management Review, 24(3), 580-582. Westport, Publisher: Quorum Books. http://dx.doi.org/10.2307/259145

Reynolds, P.D. (2000). National panel study of US business start-ups: Background and methodology. In Katz, J.A. (ed.), Advances in entrepreneurship, firm emergence and growth, 4, 153-227. Stanford, Publisher: JAI Press, ISBN: 0762303255.

Shane, S., \& Venkataraman, S. (2000). The Promise of Entrepreneurship as a Field of Research. Academy of Management Review, 25(1), 217-226. http://dx.doi.org/10.2307/259271

Shapero, A. (1975). The displaced uncomfortable entrepreneur. Psychology Today, 9(6), 83-88. Retrieved from http://ssrn.com/abstract=1506368

Smith, A. (1976). An inquiry into the nature and causes of the wealth of nations. The Economic Journal, 14(56), 599. http://dx.doi.org/10.2307/2221259

Stevenson, H. H., \& Gumpert, D. (1985). The Heart of Entrepreneurship. Harvard Business Review, 63(2), 85-94. Publisher: Edward Elgar, ISSN: 0017-8012.

Stevenson, H.H., \& Jarillo, I.C. (1990). A Paradigm of Entrepreneurship: Entrepreneurial

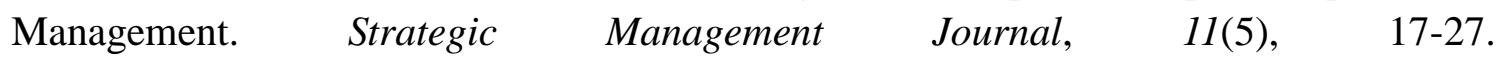
http://dx.doi.org/10.1007/3-540-48543-0_7

Venkataraman, S. (1997). The Distinctive Domain of Entrepreneurship Research. In Katz, J.A. (ed.), Advances in entrepreneurship, firm emergence and growth, 3(1), 119-138, Publisher: JAI Press, ISSN: 1074-7540.

Zahra, S., \& Dess, G. G. (Jan. 2001). Entrepreneurship as a field of research: Encouraging Dialogue and debate. Academy of Management Review, 26(1), 8-10. Retrieved from http://www.jstor.org/stable/259386. 


\section{Copyright Disclaimer}

Copyright reserved by the author(s).

This article is an open-access article distributed under the terms and conditions of the Creative Commons Attribution license (http://creativecommons.org/licenses/by/3.0/). 